\title{
Sleep Deprivation Enhances Cocaine Conditioned Place Preference in an Orexin Receptor-Modulated Manner
}

\author{
(ㄱ)Theresa E. Bjorness ${ }^{1,2}$ and ${ }^{-}$Robert W. Greene ${ }^{2,3,4}$
}

https://doi.org/10.1523/ENEURO.0283-20.2020

${ }^{1}$ Research Service, VA North Texas Health Care System, Dallas, TX 75126-7167, ${ }^{2}$ Department of Psychiatry, University of Texas Southwestern Medical Center, Dallas, TX 75390-9111, ${ }^{3}$ Department of Neuroscience, Peter O'Donnell Jr. Brain Institute, University of Texas Southwestern Medical Center, Dallas, TX 75390-9111, and ${ }^{4}$ International Institute for Integrative Sleep Medicine, University of Tsukuba, Tsukuba 305-8577, Japan

\begin{abstract}
Drug addiction and withdrawal are characterized by sleep disruption, but the effects of sleep disruption on these states are not well characterized. Sleep deprivation (SD) immediately before the cocaine conditioning trials enhanced cocaine conditioned place preference (CPP) in a dose-dependent manner $(3,8 \mathrm{mg} / \mathrm{kg}$ but not $15 \mathrm{mg} / \mathrm{kg})$ in mice. SD immediately before the postconditioning test also enhanced cocaine CPP preference in a dose-dependent manner $(8 \mathrm{mg} / \mathrm{kg}$, but not 3,15 mg/kg). Exposure to orexin-receptor antagonism $(1 \mathrm{mg} / \mathrm{kg} \mathrm{SB} 334867$, an orexin 1 receptor antagonist; OX1R) just before cocaine-conditioning trials or the postconditioning test attenuated SD-enhanced preference. This suggests a potential therapeutic role for the manipulation of the orexin system to mitigate drug seeking, especially in the context of sleep loss before drug exposure.
\end{abstract}

Key words: cocaine; conditioned place preference; mouse; orexin; sleep deprivation

\section{Significance Statement}

Drugs of abuse, including cocaine, disturb sleep, and sleep disturbance has been implicated in probability of relapse; however, there have been few direct tests of sleep disturbance on drug-seeking behavior. Here, we show that acute $(4 \mathrm{~h})$ sleep deprivation (SD) enhances the rewarding properties of cocaine, a drug with high abuse potential. Furthermore, antagonism of orexin-system neuromodulation, involved in motivationbased arousal, reduces this SD-induced enhancement of cocaine preference.

Received June 29, 2020; accepted September 12, 2020; First published October 23, 2020.

The authors declare no competing financial interests.

Author contributions: T.E.B. and R.W.G. designed research; T.E.B. performed research; T.E.B. analyzed data; T.E.B. and R.W.G. wrote the paper.

This work was supported by the Department of Veterans Affairs Award Number IK2BX002531 (to T.E.B.). The views expressed in this article are those of the authors and do not necessarily reflect the position or policy of the Department of Veterans Affairs or the United States government.

Acknowledgements: We thank Shari Birnbaum and David Self for their thoughtful suggestions regarding experimental design and data interpretation.

Correspondence should be addressed to Theresa E. Bjorness at theresa. bjorness@va.gov.

https://doi.org/10.1523/ENEURO.0283-20.2020

Copyright (c) 2020 Bjorness and Greene

This is an open-access article distributed under the terms of the Creative Commons Attribution 4.0 International license, which permits unrestricted use, distribution and reproduction in any medium provided that the original work is properly attributed.

\section{Introduction}

Cocaine, a psychostimulant with high abuse potential because of its strong reinforcing properties (Johanson et al., 1976; Bozarth and Wise, 1985), blocks monoaminergic transporters. Of these, the dopamine transporter blockade is predominately responsible for reinforcement (Ritz et al., 1987). Cocaine is readily self-administered in non-humans to the point that unlimited access is often fatal (Johanson et al., 1976; Bozarth and Wise, 1985). These appetitive properties can be measured using conditioned place preference (CPP; Bardo and Bevins, 2000): an associative learning task in which rewarding properties of stimuli are inferred based on time spent in a context associated with a specific drug/stimuli (such as cocaine) relative to a neutral stimuli (such as saline). As expected for a drug that produces reinforcement, animals show 
preference for environments in which they have previously received cocaine (Mucha et al., 1982; Spyraki et al., 1982).

Acute cocaine exposure potentiates arousal by increasing sleep latency and increasing the amount of time in waking in a dose-dependent manner (Dugovic et al., 1992; Knapp et al., 2007; Bjorness and Greene, 2018a). Increases in subsequent sleep compensate for the sleep loss to the extent that there is no overall change in the amount of sleep/waking over the 24-h period in response to either acute (Bjorness and Greene, 2018a) or to several days of repeated (Dugovic et al., 1992) cocaine exposure. Non-compensated reductions in sleep are observed following withdrawal from cocaine self-administration, with decreases in non-rapid eye movement sleep emerging one week into withdrawal, decreases in rapid eye movement sleep emerging $1 \mathrm{~d}$ into withdrawal, and decreases in both persisting through three weeks of withdrawal (Chen et al., 2015). Thus, chronic sleep disturbance emerges after more extensive exposure to cocaine, while limited cocaine induces a sleep deprivation (SD) plus recovery response.

SD can influence drug use, as suggested by evidence that subjective sleep quality is a robust predictor of relapse to alcohol consumption (Brower et al., 2001) and that lack of Slow Wave Sleep (SWS) time recovery across abstinence is associated with relapse to cocaine use (Angarita et al., 2014). Furthermore, subjective sleep disturbance is associated with cocaine relapse following treatment in a large cohort study (Dolsen and Harvey, 2017). In rodents, chronic sleep restriction can increase motivation for cocaine (i.e., the amount of work an animal will do to obtain a cocaine reward) in a subset of animals (Puhl et al., 2013). SD also influences reward in that SD increases preference for the stimulant methylphenidate in humans (Roehrs et al., 1999) and induces preference to a low dose of amphetamine in mice (Berro et al., 2018).

The mechanism/s by which sleep loss could influence reward seeking have yet to be determined; however, the peptide neuromodulator orexin (also known as hypocretin) shows differential activity across sleep/waking states with increased activity during extended waking (i.e., SD) compared with typical waking (Estabrooke et al., 2001; Yoshida et al., 2001), is modulated by cocaine and other drugs of abuse (Thannickal et al., 2018; James et al., 2019), and influences reward seeking (Hollander et al., 2012; Gentile et al., 2018), making it an attractive candidate system. Furthermore, since orexin is heavily implicated in both maintenance of arousal (Sakurai et al., 2010) and motivated behavior (James et al., 2017), it has been hypothesized to integrate arousal and motivation (Tyree et al., 2018).

In the present study, we tested the hypothesis that acute SD enhances cocaine CPP and that the orexin system has an important role in this modulation.

\section{Materials and Methods}

\section{Animals}

Adult male C57BL/6 mice were obtained from Charles River Laboratories. Mice were assigned into groups (described in study 1, 2, 3, and 4 sections below) and placed into cages atop a treadmill apparatus with food and water available ad libitum in rooms with an ambient temperature of $22.0 \pm 1^{\circ} \mathrm{C}$ and a $12 / 12 \mathrm{~h}$ light/dark cycle. All experiments were approved by the VA North Texas Health Care System IACUC and were in accordance with recommendations in the Guide for Care and Use of Laboratory Animals (United States National Research Council).

\section{Cocaine CPP}

An unbiased design was used with three chambered CPP boxes (Med Associates). These boxes were unbiased in that there was no overall preference for either of the side chambers which feature different wall and flooring patterns to make them easily distinguishable. First, mice were given a preconditioning test in which they were placed into the center chamber (doors open) and allowed to explore for $20 \mathrm{~min}$. Mice were excluded if they showed an innate preference for either side (as defined by $>20 \%$ difference in percent time spent between sides) or if they spent more time in the center chamber than either side chamber. A subset of "excluded" mice underwent a second preconditioning test using a different CPP box (featuring different floor and wall patterns). These double pretested animals were divided evenly across groups. Next, mice underwent four conditioning trials (doors closed) in which they received cocaine $(3,8$, or $15 \mathrm{mg} / \mathrm{kg}$ ) or saline (vehicle control) with one, 30-min trial per day. Finally, mice were given a 20-min postconditioning test (doors open). Testing and conditioning trials occurred between zeitgeber time (ZT)4 and ZT7 and were conducted under low light level to encourage exploration. Time in each chamber was determined by IR beam break (automated) or video (manual). Based on previous reports, preference is expected for the $8 \mathrm{mg} / \mathrm{kg}$ dose (Campbell et al., 2000) and for the $15 \mathrm{mg} /$ $\mathrm{kg}$ dose (Nomikos and Spyraki, 1988) but not for the $3 \mathrm{mg} /$ kg dose (Zachariou et al., 2001). While conditioning protocols vary, two trials are expected to be sufficient to support the development of cocaine preference (McClung et al., 2005; Graham et al., 2009).

\section{Cocaine CPP study 1 (Fig. 1A)}

For each cocaine dose $(3,8,15 \mathrm{mg} / \mathrm{kg})$, two groups of animals were compared [group names are designated based on the sleep parameters (SD or undisturbed; noSD) before each set of conditioning trials (cocaine, Coc; or saline, Sal)]. Both groups received cocaine and saline on alternating days. The experimental group of mice underwent $\mathrm{SD}$ for $4 \mathrm{~h}$ immediately before cocaine conditioning trials and, on alternate days, were undisturbed before saline conditioning trials (SD Coc, noSD Sal). The control group was sleep deprived for $4 \mathrm{~h}$ immediately before the saline conditioning trials (noSD Coc, SD. Sal) but was undisturbed before the cocaine conditioning trials. An additional experiment was used to test whether SD is sufficient to induce preference. Subjects received saline on both side chambers with (SD Sal, noSD Sal) or without SD (noSD Sal, 
noSD Sal) before saline-conditioning trials on one side of the box. Animals were weighed before each conditioning trial. There was no difference in preconditioning relative time values (side $\mathrm{A}$ - side $\mathrm{B}$ ) between groups for any of the doses $(0 \mathrm{mg} / \mathrm{kg}, p=0.96 ; 3 \mathrm{mg} / \mathrm{kg}, p=0.98 ; 8 \mathrm{mg} / \mathrm{kg}$, $p=0.99 ; 15 \mathrm{mg} / \mathrm{kg}, p=0.71)$.

\section{Cocaine CPP study 2 (Fig. 2A)}

For each cocaine dose $(3,8,15 \mathrm{mg} / \mathrm{kg})$, two groups of animals were compared [group names are designated based on the sleep parameters, SD undisturbed (noSD), before the postconditioning test]. Both groups received cocaine and saline on alternating days. In this study, the experimental group of mice was sleep deprived on only one occasion, i.e., $4 \mathrm{~h}$ immediately before the post-test (SD), while a control group was undisturbed (noSD). There was no difference in preconditioning relative time values between groups for any of the doses $(3 \mathrm{mg} / \mathrm{kg}, p=0.99$; $8 \mathrm{mg} / \mathrm{kg}, p=0.73 ; 15 \mathrm{mg} / \mathrm{kg}, p=0.68)$.

\section{Orexin-receptor antagonism during conditioning and SD-enhanced cocaine CPP study 3 (Fig. 3A)}

Subsets of mice receiving 3 or $8 \mathrm{mg} / \mathrm{kg}$ cocaine were injected with the orexin 1 receptor (OX1R) antagonist SB 334867 (1 mg/kg; SB) or vehicle (Veh) $15 \mathrm{~min}$ before the conditioning trials (group names are designated based on sleep parameters and OX1R-antagonism status before each conditioning test). The experimental group was sleep deprived for $4 \mathrm{~h}$ and given SB before cocaine conditioning trials (SD SB Coc, noSD Veh Sal), while a control subset of mice was sleep deprived and given SB before the saline paired trials (noSD Veh Coc, SD SB Sal). For the $8 \mathrm{mg} / \mathrm{kg}$ dose, a third subset of mice was injected with SB

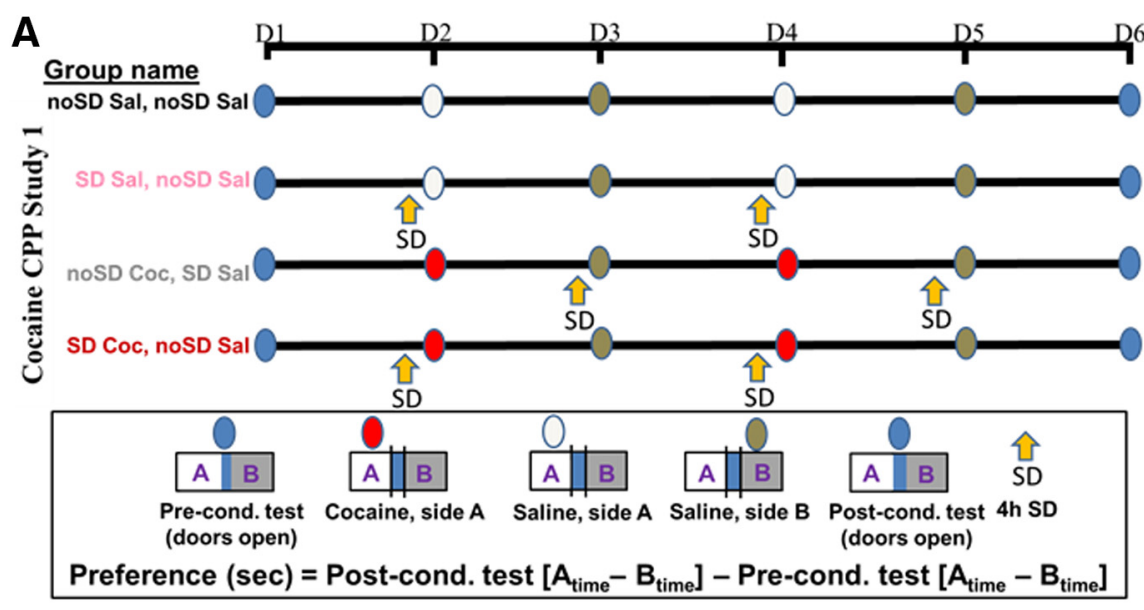

B

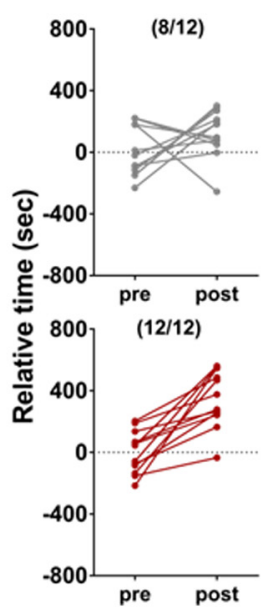

C
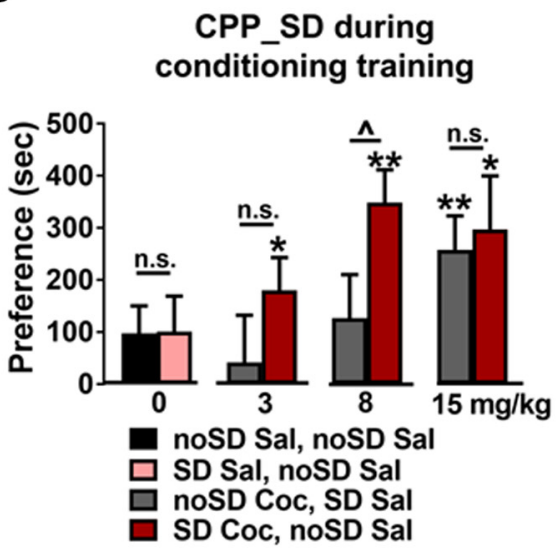

Figure 1. A, Experimental timeline of cocaine CPP study 1. B, Following conditioning to $8 \mathrm{mg} / \mathrm{kg}$ cocaine, most animals undisturbed before cocaine conditioning trials spent more time in the cocaine-paired side following conditioning as expected as compared with their preconditioning test times (top), which shifted to all animals when SD occurred immediately before cocaine conditioning trials (bottom). C, SD immediately before cocaine conditioning trials induced preference to $3 \mathrm{mg} / \mathrm{kg}$ cocaine and enhanced preference to $8 \mathrm{mg} / \mathrm{kg}$ cocaine without altering preference to $15 \mathrm{mg} / \mathrm{kg}$ cocaine. SD in the absence of cocaine $(0 \mathrm{mg} / \mathrm{kg})$ did not induce preference. Asterisks above columns indicate preference (as determined by a significant difference from 0 ), the carrot between columns indicates a significant difference between groups, and n.s. indicates a lack of significant difference between groups. Bars indicate group average, error bars indicate standard error of the mean (SEM). 
before the cocaine paired trials but was not sleep deprived, serving as an OX1R antagonist-only control (noSD SB Coc, noSD Veh Sal). There was no difference in preconditioning relative time values between groups at either dose ( $3 \mathrm{mg} / \mathrm{kg}, p=0.9 ; 8 \mathrm{mg} / \mathrm{kg}, p=0.99)$. SB 334867 was chosen on the basis of its common use in addiction-related studies, while the cocaine doses chosen were based on the doses in which there were significant group differences in study $1(3,8 \mathrm{mg} / \mathrm{kg})$.

\section{OX1R antagonism after conditioning and SD- enhanced cocaine CPP study 4 (Fig. 4A)}

Subsets of mice receiving $8 \mathrm{mg} / \mathrm{kg}$ cocaine were injected with SB $15 \mathrm{~min}$ before the post-test. The experimental group was sleep deprived for $4 \mathrm{~h}$ before receiving SB (SD $\mathrm{SB}$ ), while the control group was undisturbed before receiving SB (noSD SB). There was no difference in preconditioning relative time values between groups $(p=0.98)$. The cocaine dose chosen was based on the dose in which there was a significant group difference in study $2(8 \mathrm{mg} / \mathrm{kg})$.

\section{SD}

Mice were sleep deprived using the treadmill method (Bjorness et al., 2009) in which waking is enforced through slow walking; the belt speed was $\sim 3 \mathrm{~cm} / \mathrm{s}$ (for comparison belt speeds of $\sim 20 \mathrm{~cm} / \mathrm{s}$ are used for exercise; Um et al., 2011). SD began early in the light phase (ZTO-ZT2) and concluded immediately before CPP conditioning or testing for a total of $4 \mathrm{~h}$. Food and water were available throughout the SD period. Four hours of SD was used since this duration reliably induces a homeostatic response as measured by an increase in slow wave activity (SWA; $0.5-4.5 \mathrm{~Hz}$ ) during slow wave sleep (Bjorness and Greene, 2018b). Furthermore, this duration does not increase expression of glucocorticoid-related genes as determined by transcriptome analysis of cortical tissue (Bjorness et al., 2020).

\section{Drugs}

Cocaine hydrochloride (Sigma-Aldrich) was dissolved in sterile saline and injected in doses of 3,8 , or $15 \mathrm{mg} / \mathrm{kg}$ with a volume of $\leq 0.1 \mathrm{ml}$. Sterile saline was used as the vehicle control. SB 334867 (Sigma-Aldrich) was dissolved in dimethyl sulfoxide (DMSO), then diluted in sterile water (10\% DMSO). DMSO diluted with sterile water was used as the vehicle control.

\section{Outcome measures}

The main outcome measure for cocaine CPP was preference score which was calculated as preference $(s)=$ postconditioning test (side $A_{\text {time }}$ - side $B_{\text {time }}$ ) - preconditioning test (side $A_{\text {time }}$ - side $B_{\text {time) }}$ ), with $A$ side conditioning in trials 1,3 and $B$ side in trials 2, 4. For studies 1 and 2 , control and experimental groups were compared using one tailed unpaired $t$ tests $(3,8$, or $15 \mathrm{mg} / \mathrm{kg}$ cocaine) or two tailed unpaired $t$ test $(0 \mathrm{mg} / \mathrm{kg}$ cocaine). For studies 3 and 4 , control and experimental groups were compared using two tailed unpaired $t$ test $(3 \mathrm{mg} / \mathrm{kg}$ study $3,8 \mathrm{mg} / \mathrm{kg}$ study 4) or one-way ANOVA with Sidak correction for multiple comparisons $(8 \mathrm{mg} / \mathrm{kg}$ study 4$)$. One tailed $t$ tests were used for comparisons in which there is literature support for an effect of SD on preference outcomes, while two tailed $t$ tests were used for comparisons lacking direct literature support for an effect of SD on preference outcomes. Additionally, preconditioning relative time values (time in side to be paired with cocaine - time in side to be paired with saline) were also compared for each experiment to ensure equal balancing (with respect to preconditioning preference time) of groups before cocaine exposure. For comparison to a theoretical mean of 0 , a two-tailed one sample $t$ test was used; positive values significantly different from 0 indicate preference. All statistical analyses were performed using GraphPad prism. Values are given as average \pm SEM, and significance is set at $p<0.05$. For all studies, preconditioning and postconditioning relative values are shown (Figs. $1 B, 2 B, 3 B, 4 B$ ) for the $8 \mathrm{mg} / \mathrm{kg}$ dose to

Table 1: Cocaine CPP, study 1

\begin{tabular}{|c|c|c|c|c|}
\hline \multirow[b]{2}{*}{ Study 1} & \multicolumn{2}{|c|}{$0 \mathrm{mg} / \mathrm{kg}$} & \multicolumn{2}{|c|}{$3 \mathrm{mg} / \mathrm{kg}$} \\
\hline & noSD Sal, no SD. Sal & SD. Sal, noSD Sal & noSD Coc, SD. Sal & SD. Coc, noSD Sal \\
\hline Mean \pm SEM & $97.81 \pm 52.49$ & $100.6 \pm 63.38$ & $41.83 \pm 90.53$ & $180.4 \pm 62.75$ \\
\hline$p$ value & 0.09 & 0.17 & 0.655 & 0.0165 \\
\hline \multirow[t]{2}{*}{ Stat used for comparison } & One sample $t$ test & One sample $t$ test & One sample $t$ test & One sample $t$ test \\
\hline & \multicolumn{2}{|c|}{$8 \mathrm{mg} / \mathrm{kg}$} & \multicolumn{2}{|c|}{$15 \mathrm{mg} / \mathrm{kg}$} \\
\hline Mean \pm SEM & $126.4 \pm 83.62$ & $348.7 \pm 62.95$ & $257.9 \pm 65.4$ & $284.9 \pm 94.67$ \\
\hline $95 \% \mathrm{Cl}$ & $-57.64-310.5$ & $210.1-487.2$ & $114-401.9$ & $76.5-493.2$ \\
\hline$p$ value & 0.1588 & 0.0002 & 0.0023 & 0.0119 \\
\hline Stat used for comparison & One sample $t$ test & One sample $t$ test & One sample $t$ test & One sample $t$ test \\
\hline Group comparison & $0 \mathrm{mg} / \mathrm{kg}$ & $3 \mathrm{mg} / \mathrm{kg}$ & $8 \mathrm{mg} / \mathrm{kg}$ & $15 \mathrm{mg} / \mathrm{kg}$ \\
\hline Difference between means & $-2.521 \pm 49.26$ & $-138.5 \pm 108.5$ & $-222.3 \pm 104.7$ & $-26.93 \pm 115.1$ \\
\hline
\end{tabular}


illustrate variability between animals within each group alongside the general pattern of increased time in the cocaine-paired side.

\section{Results}

\section{Cocaine CPP, study 1}

To examine the effects of SD on cocaine CPP, we compared CPP in experimental and control groups of mice. Both groups were alternately (every other day) conditioned to cocaine and saline (Coc, Sal); however, the experimental group's cocaine conditioning was preceded by $4 \mathrm{~h}$ of SD (SD. Coc, noSD Sal) whereas the control group's saline conditioning was preceded by SD (noSD Coc, SD. Sal) as illustrated in Figure $1 A$. To control for the potential effects of SD in the absence of cocaine conditioning, an additional two cohorts of mice received saline every day either with (SD. Sal, noSD Sal) or without SD (noSD Sal, noSD Sal).

As expected, most animals (8/12 noSD Coc, SD. Sal, $12 / 12$ SD. Coc, noSD Sal) that received the $8 \mathrm{mg} / \mathrm{kg}$ dose of cocaine showed an increase in the time spent in the cocaine-paired side, tested after conditioning (Fig. 1B); however, SD immediately before cocaine conditioning trials resulted in an increase in time spent on the cocainepaired side over animals experiencing SD preceding saline (Fig. 1C; Table 1). In the absence of SD, animals did not show any preference for the $3 \mathrm{mg} / \mathrm{kg}$ cocaine-conditioned side. In contrast, SD immediately before cocaine conditioning trials induced preference to a $3 \mathrm{mg} / \mathrm{kg}$ dose of cocaine (Fig. 1C; Table 1). SD did not influence preference to a $15 \mathrm{mg} / \mathrm{kg}$ dose of cocaine, a possible ceilinglike effect (Fig. 1C; Table 1). Controls (noSD Coc, SD Sal) showed preference at $15 \mathrm{mg} / \mathrm{kg}$ but not at $8 \mathrm{mg} / \mathrm{kg}$, possibly because of high variability driven by one animal (not identified as an outlier when using the ROUT method; GraphPad Prism). SD in the absence of cocaine did not induce preference (0 mg/kg; Fig. $1 C$; Table 1$)$.

\section{Cocaine CPP, study 2}

To examine the effects of SD on cocaine CPP after conditioning has been established, cocaine-conditioned animals underwent SD for $4 \mathrm{~h}$ immediately before the

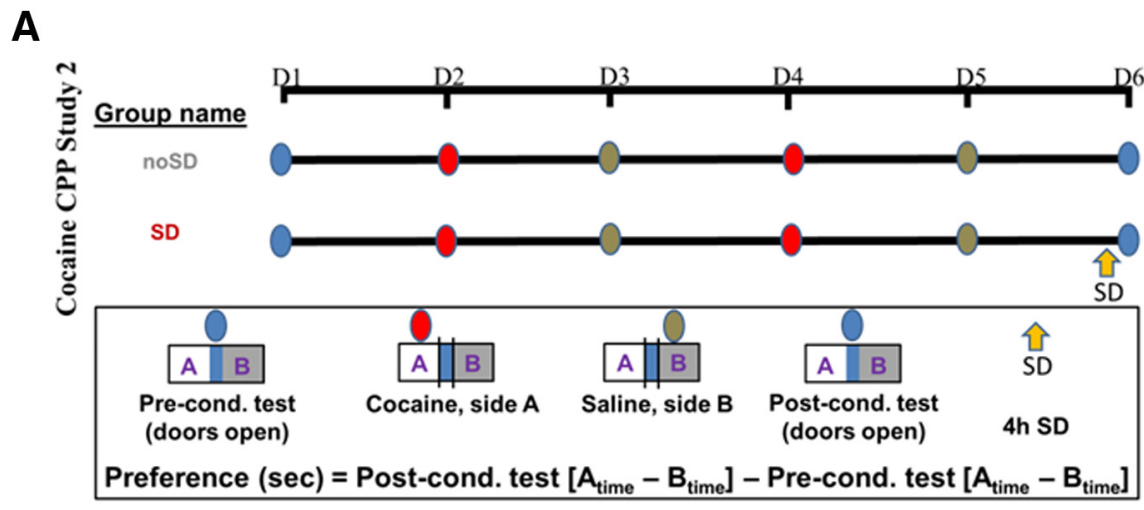

B

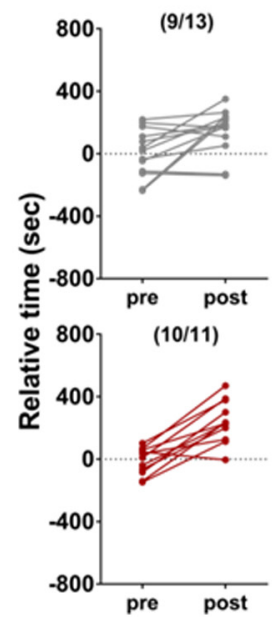

C

\section{CPP SD after conditioning training}

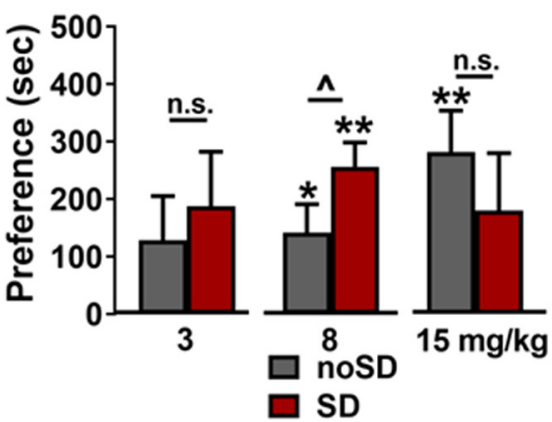

Figure 2. $\boldsymbol{A}$, Experimental timeline for the cocaine CPP study 2. $\boldsymbol{B}$, Following conditioning to $8 \mathrm{mg} / \mathrm{kg}$ cocaine, most animals undisturbed before the postconditioning test spent more time in the cocaine-paired side as compared with their preconditioning test times (top), which shifted to a higher proportion of animals when SD occurred immediately before the postconditioning test (bottom). C, SD immediately before postconditioning test induced a non-significant trend toward preference to $3 \mathrm{mg} / \mathrm{kg}$ cocaine and enhanced preference to $8 \mathrm{mg} / \mathrm{kg}$ cocaine, while reducing preference to a non-significant trend to $15 \mathrm{mg} / \mathrm{kg}$ cocaine. Asterisks above columns indicate preference (as determined by a significant difference from 0), the carrot between columns indicates a significant difference between groups, and n.s. indicates a lack of significant difference between groups. Bars indicate group average, error bars indicate SEM. 
Table 2: Cocaine CPP, study 2

\begin{tabular}{|c|c|c|c|c|c|c|}
\hline \multirow[b]{2}{*}{ Study 2} & \multicolumn{2}{|c|}{$3 \mathrm{mg} / \mathrm{kg}$} & \multicolumn{2}{|c|}{$8 \mathrm{mg} / \mathrm{kg}$} & \multicolumn{2}{|c|}{$15 \mathrm{mg} / \mathrm{kg}$} \\
\hline & noSD & SD & nosD & SD & noSD & SD \\
\hline Mean \pm SEM & $128.3 \pm 76.91$ & $187.4 \pm 94.94$ & $141.3 \pm 49.55$ & $256 \pm 42.39$ & $281.8 \pm 72.06$ & $179.6 \pm 100.1$ \\
\hline$p$ value & 0.1236 & 0.0767 & 0.0146 & 0.0001 & 0.0024 & 0.1005 \\
\hline Stat used for comparison & $\begin{array}{l}\text { One sample } t \\
\text { test }\end{array}$ & $\begin{array}{l}\text { One sample } t \\
\text { test }\end{array}$ & $\begin{array}{l}\text { One sample } t \\
\text { test }\end{array}$ & $\begin{array}{l}\text { One sample } t \\
\text { test }\end{array}$ & $\begin{array}{l}\text { One sample } t \\
\text { test }\end{array}$ & $\begin{array}{l}\text { One sample } t \\
\text { test }\end{array}$ \\
\hline Difference between means & -59.1 & 121.3 & $114.7=$ & 66.55 & 102.3 & 123.4 \\
\hline $95 \% \mathrm{Cl}$ & -311 & -193.1 & -23.31 & -252.7 & -153. & -358.1 \\
\hline$p$ value & & & 0.0 & & & 81 \\
\hline Stat used for comparison & $\begin{array}{l}\text { Unp } \\
\text { test, }\end{array}$ & $\begin{array}{l}\text { red } t \\
\text { le tailed }\end{array}$ & $\begin{array}{l}\text { Unpa } \\
\text { test, o }\end{array}$ & $\begin{array}{l}\text { ed } t \\
\text { e tailed }\end{array}$ & $\begin{array}{r}\text { Unpair } \\
\text { on }\end{array}$ & $\begin{array}{l}\text { d } t \text { test, } \\
\text { tailed }\end{array}$ \\
\hline
\end{tabular}

A

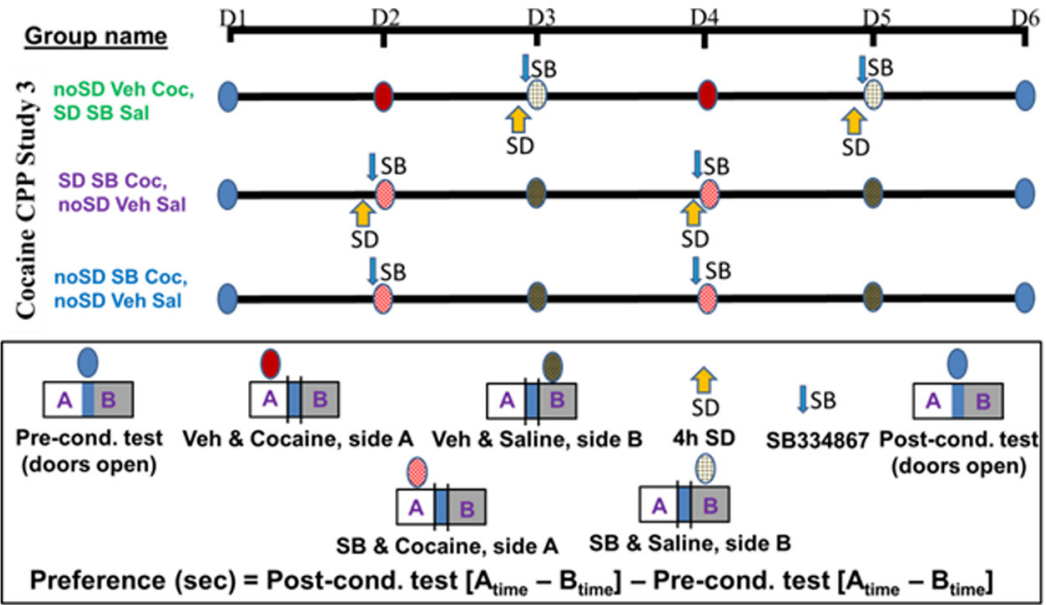

B

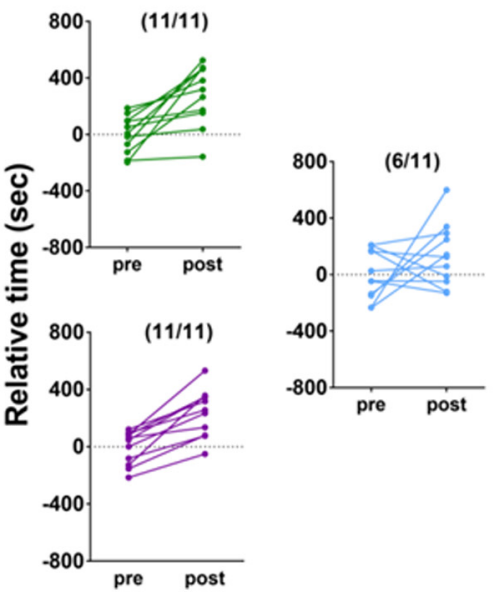

C CPP_SD and OX1R during conditioning training

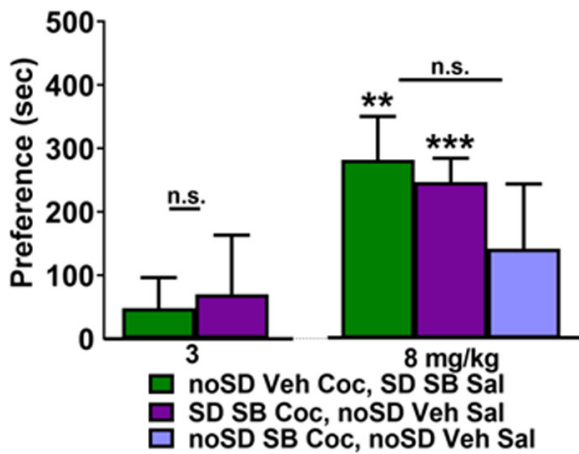

Figure 3. A, Experimental timeline for the cocaine CPP study 3. B, All animals spent more time in the cocaine-paired side following conditioning as compared with their preconditioning test values when Veh was administered before the cocaine trials (top) or when SB 334867 was administered immediately following SD (bottom); however, only a subset of animals spent more time in the cocainepaired side when SB 334867 was administered in the absence of SD (right side). C, OX1R antagonism before cocaine conditioning trials blocked the SD-induced preference to $3 \mathrm{mg} / \mathrm{kg}$ cocaine and the SD-induced enhanced preference to $8 \mathrm{mg} / \mathrm{kg}$ cocaine, while OX1R antagonism in the absence of SD prevented the acquisition of preference to $8 \mathrm{mg} / \mathrm{kg}$ cocaine. Asterisks above columns indicate preference (as determined by a significant difference from 0), and n.s. indicates a lack of significant difference between groups. Bars indicate group average, error bars indicate SEM. 
postconditioning test. The control group was similarly conditioned but remained undisturbed before testing for CPP (Fig. 2A).

As expected, most animals ( $n=9 / 13$ noSD; 10/11 SD) that received the $8 \mathrm{mg} / \mathrm{kg}$ dose of cocaine showed an increase in the time spent in the cocaine-paired side from the preconditioning to postconditioning tests (Fig. 2B). SD immediately before the postconditioning test induced a non-significant trend toward preference to a $3 \mathrm{mg} / \mathrm{kg}$ dose of cocaine (Fig. 2C; Table 2) and significantly increased preference to an $8 \mathrm{mg} / \mathrm{kg}$ dose of cocaine (Fig. $2 C$; Table 2). There was no difference in preference between groups to a $15 \mathrm{mg} / \mathrm{kg}$ dose of cocaine (Fig. 2C; Table 2), but the sleep-deprived group showed a non-significant trend toward preference for the cocaine-paired side.

\section{OX1R antagonism during conditioning and SD-enhanced cocaine CPP, study 3}

A previous observation indicates that SB 334867 during conditioning attenuates cocaine CPP (Rao et al., 2013). To examine the effects of OX1R antagonism on SD-induced enhancement of cocaine CPP, we compared CPP in an experimental and control group as in study 1, except that immediately following $S D$, but before each training session, animals received the OX1R antagonist SB 334867 (SB) or vehicle (Veh) on alternating days (Fig. 3A). To test for OX1R antagonism effects in the absence of SD, SB 334867 was also given to cohort that did not undergo SD.

In response to $8 \mathrm{mg} / \mathrm{kg}$ cocaine, all sleep-deprived animals showed an increase in the time spent on the cocainepaired side; however, only a subset (6/11) of animals receiving OX1R antagonism in the absence of SD showed this relative increase (Fig. $3 B$ ). In contrast to the observations of study 1 in which SD induced cocaine CPP to a $3 \mathrm{mg} / \mathrm{kg}$ dose of cocaine, SB 334867 prevented this induction. Finally, SB 334867 prevented preference in the absence of SD and blocked SD-induced enhancement of preference to a $8 \mathrm{mg} / \mathrm{kg}$ dose of cocaine as determined by a lack of difference between groups; however SD animals treated with SB 334867 did show preference for the cocaine-paired side suggesting that SD-dependent enhancement is reduced but not entirely prevented (Fig. 3C; Table 3).

\section{OX1R antagonism after conditioning and SD- enhanced cocaine CPP, study 4}

Previous observations indicate that SB after conditioning does not influence cocaine CPP (Sharf et al., 2010; Sartor and Aston-Jones, 2012). The effect of OX1R antagonism together with SD on cocaine CPP after establishment of conditioning was examined by comparing CPP in an experimental and control group of mice as in study 2 , except that all animals received the OX1R antagonist before the postconditioning test (Fig. 4A).

A similar majority of undisturbed or sleep-deprived animals administered SB 334867 just before the postconditioning test, showed an increase in the time spent on the cocaine-paired side (Fig. 4B). The antagonism of OX1R after establishment of conditioning was sufficient to prevent the SD-induced enhancement of cocaine CPP to an $8 \mathrm{mg} / \mathrm{kg}$ dose of cocaine (Fig. 4C; Table 4).

\section{SD shifts the cocaine CPP dose-response curve leftward in an orexin-influenced manner}

SD immediately before cocaine-conditioning trials shifts the preference dose-response curve leftward (Fig. 5A) which is consistent with an increasing sensitivity to the rewarding properties of cocaine. However, OX1R antagonism immediately before the cocaine-conditioning trials reduces this shift (Fig. 5B). An SD-related leftward shift in the dose-response curve is also apparent when SD occurs

Table 3: Cocaine CPP, study 3

\begin{tabular}{|c|c|c|c|c|c|}
\hline \multirow[b]{2}{*}{ Study 3} & \multicolumn{2}{|l|}{$3 \mathrm{mg} / \mathrm{kg}$} & \multicolumn{3}{|c|}{$8 \mathrm{mg} / \mathrm{kg}$} \\
\hline & $\begin{array}{l}\text { noSD Veh } \\
\text { Coc, SD SB Sal }\end{array}$ & $\begin{array}{l}\text { SD SB Coc, } \\
\text { noSD Veh Sal }\end{array}$ & $\begin{array}{l}\text { noSD Veh Coc, } \\
\text { SD SB Sal }\end{array}$ & $\begin{array}{l}\text { SD SB Coc, } \\
\text { noSD Veh Sal }\end{array}$ & $\begin{array}{l}\text { noSD SB Coc, } \\
\text { noSD Veh Sal }\end{array}$ \\
\hline$N$ & 11 & 12 & 11 & 11 & 11 \\
\hline $95 \% \mathrm{Cl}$ & $-59.36-155.6$ & $-134.8-275.3$ & $129.5-434.5$ & $162.8-330.7$ & $-85.82-369.4$ \\
\hline$p$ value & 0.342 & 0.4666 & 0.0021 & $<0.0001$ & 0.1953 \\
\hline $\begin{array}{l}\text { Stat used for } \\
\text { comparison }\end{array}$ & One sample $t$ test & One sample $t$ test & One sample $t$ test & $\begin{array}{l}\text { One sample } t \\
\text { test }\end{array}$ & $\begin{array}{l}\text { One sample } t \\
\text { test }\end{array}$ \\
\hline $\begin{array}{l}\text { Group } \\
\text { comparison }\end{array}$ & $\begin{array}{l}3 \mathrm{mg} / \mathrm{kg} \\
\text { noSD Veh Coc, } \\
\text { SD SB Sal vs SD } \\
\text { SB Coc, noSD Veh Sal }\end{array}$ & $\begin{array}{l}8 \mathrm{mg} / \mathrm{kg} \\
\text { noSD Veh Coc, } \\
\text { SD SB Sal vs SD } \\
\text { SB Coc, noSD Veh } \\
\text { Sal }\end{array}$ & $\begin{array}{l}8 \mathrm{mg} / \mathrm{kg} \\
\text { noSD Veh Coc, } \\
\text { SD SB Sal vs noSD } \\
\text { SB Coc, noSD Veh } \\
\text { Sal }\end{array}$ & & \\
\hline $\begin{array}{l}\text { Difference between } \\
\text { means }\end{array}$ & $22.13 \pm 107.8$ & $35.25 \pm 105$ & $140.2 \pm 105$ & & \\
\hline
\end{tabular}


A

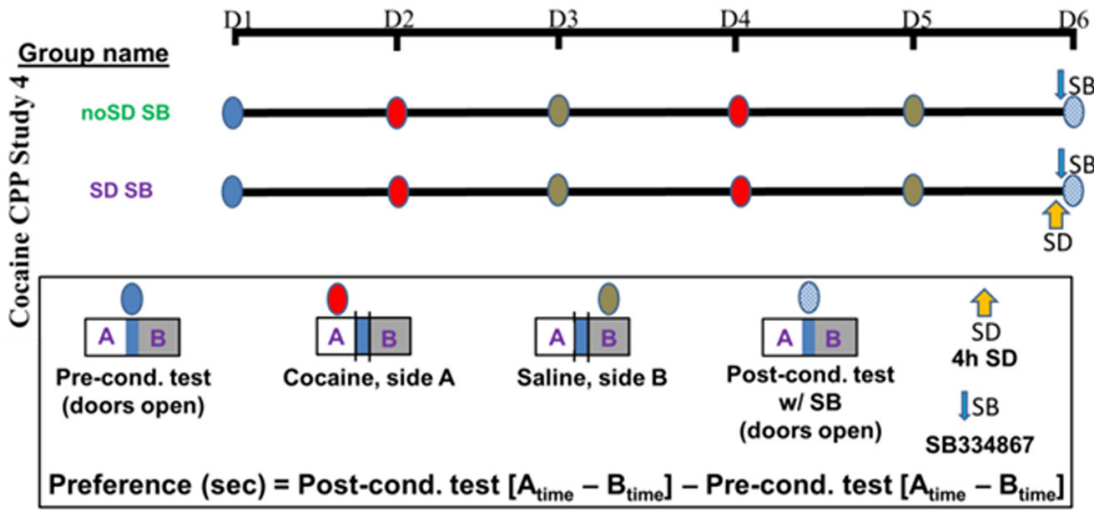

B

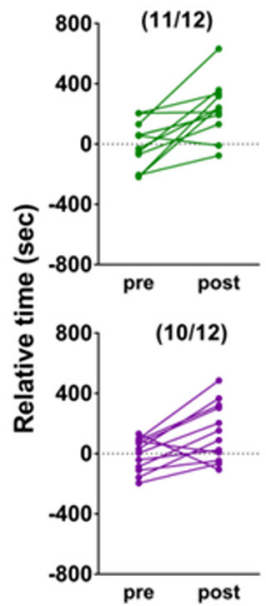

C

\section{CPP expression with OX1R}

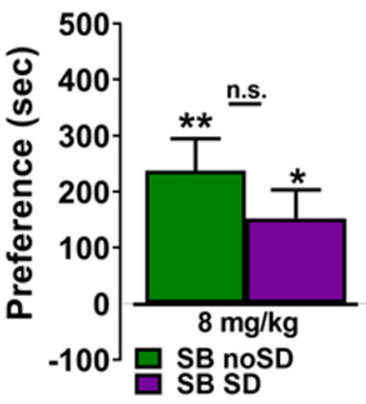

Figure 4. A, Experimental timeline for cocaine CPP study 4. B, Most animals spent more time in the cocaine-paired side following conditioning as compared with their preconditioning test values both when undisturbed animals were administered SB 334687 before the postconditioning test (top) and when sleep-deprived animals were administered SB 334867 before the postconditioning test (bottom). C, OX1R antagonism prevents the SD-induced increase in preference to $8 \mathrm{mg} / \mathrm{kg}$ cocaine, although both groups show preference for the cocaine-paired side. Asterisks above columns indicate preference (as determined by a significant difference from $0)$, and n.s. indicates a lack of significant difference between groups. Bars indicate group average, error bars indicate SEM.

immediately before the postconditioning test (Fig. 5C) and it is reduced by OX1R antagonism. Unexpectedly, OX1R antagonism in undisturbed animals before the postconditioning test (study 4; noSD SB) led to preference values similar to that of sleep-deprived animals in the absence of OX1R antagonism (study 2; SD), thereby reversing the polarity of the effect of SD as determined by dividing the group average preference score of the sleep-deprived

Table 4: Cocaine CPP, study 4

\begin{tabular}{lll}
\hline Study 4 & noSD SB & $8 \mathrm{mg} / \mathrm{kg}$ \\
\hline$N$ & 12 & SD SB \\
Mean \pm SEM & $237.4 \pm 57.03$ & 12 \\
$95 \% \mathrm{Cl}$ & $111.8-362.9$ & $40.17-264.1$ \\
$p$ value & 0.0016 & 0.0123 \\
Stat used for comparison & One sample $t$ test & One sample $t$ test \\
& & 80.88 \\
Group comparison & $8 \mathrm{mg} / \mathrm{kg}$ & $-85.21 \pm 76.42$ \\
Difference between means & $-243.7-73.28$ & \\
$95 \% \mathrm{Cl}$ & 0.2769 & \\
$p$ value & Unpaired $t$ test, two tailed & \\
Stat used for comparison & &
\end{tabular}


A
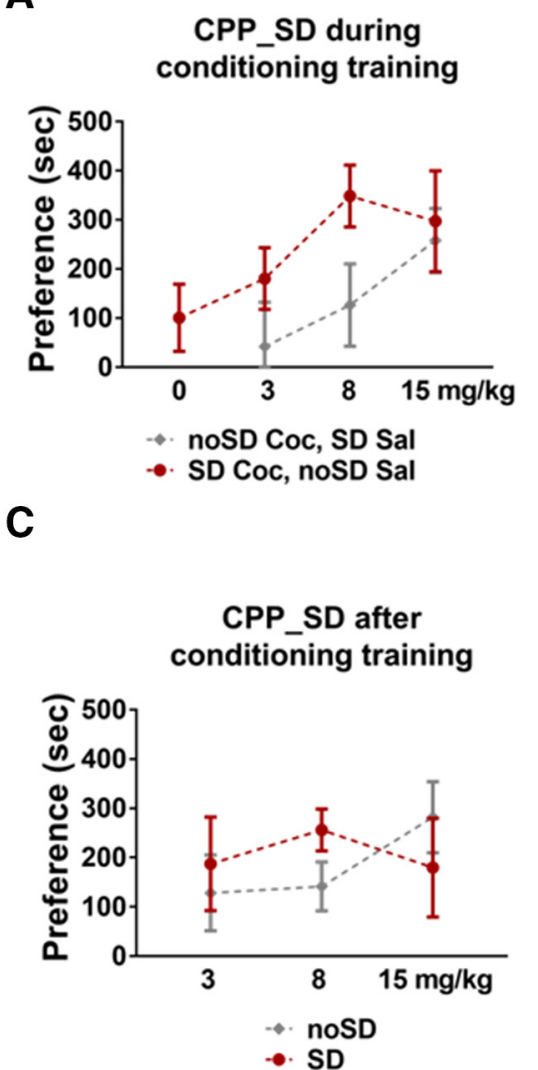

B

\section{CPP_SD and OX1R \\ during conditioning training}

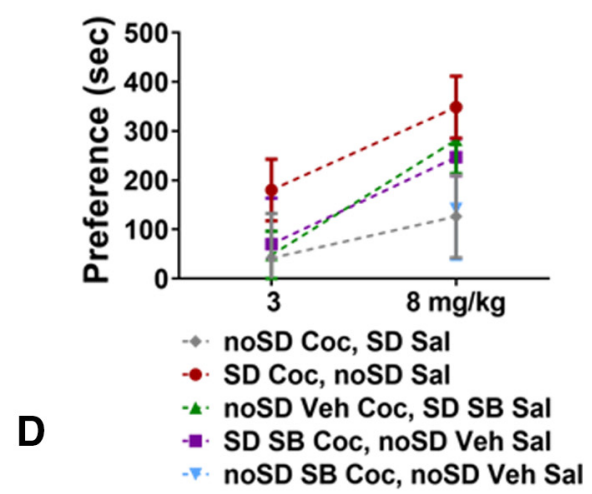

CPP_OX1R reverses polarity of SD response

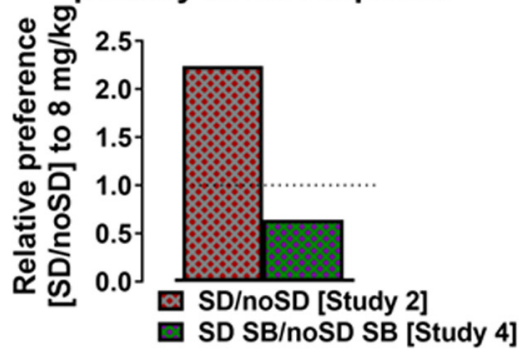

Figure 5. A, Dose-response plot of preference from cocaine CPP study 1 in which SD shifts the curve leftward (data replotted from Fig. $1 C)$. $\boldsymbol{B}$, OX1R antagonism mitigates the SD-induced shift in the dose-response curve (data replotted from Figs. $1 C, 3 C$ ). $\boldsymbol{C}$, Dose-response plot of preference from cocaine CPP study 2 in which SD shifts the curve leftward, although to a lesser degree than under cocaine CPP study 1 (data replotted from Fig. 2C). D, The SD enhancement of relative preference, as determined by the ratio of average preference in SD and noSD groups (from study 2) and indicated by $>1$ value (left bar), is blocked by OX1R antagonism (SD SB/noSD SB from study 4; right bar). Notably, the relative preference of $<1$ under OX1R antagonism indicates that OX1R antagonism in the presence of SD reduces relative preference, while OX1R antagonism in the absence of SD increases relative preference.

group by the group average preference score of the undisturbed group [i.e., (study 2, SD/noSD); (study 4, SD SB/ noSD SB)]. A score above 1 indicates that SD results in a higher relative preference score compared with the undisturbed condition, while a score below 1 indicates that SD results in a lower relative preference score compared with the undisturbed condition. Statistical comparisons across studies were not performed because of data collection constraints (see limitations paragraph within Discussion) so these comparisons are observational in nature and should be interpreted with caution.

\section{Discussion}

SD enhanced cocaine CPP in a dose-dependent manner resulting in a leftward shift in the dose-response curve, indicating SD increased the rewarding properties of cocaine. This shift was more pronounced when SD occurred immediately before cocaine exposure compared with SD after cocaine conditioning was already established, consistent with a greater SD-induced enhancement of acquisition of preference than of its expression. OX1R antagonism reduced the SD-induced enhancement of both acquisition and expression.
On the low end of the dose-response curve, SD induced preference to a subthreshold dose of cocaine, which is similar to a previously reported SD-dependent induction of preference to subthreshold amphetamine (Berro et al., 2018), suggesting SD may increase sensitivity to psychostimulants in general. On the high end of the dose-response curve, SD did not alter preference to a sensitizing dose of cocaine, possibly because of a ceiling effect and/or, an aversive effect elicited by higher doses of cocaine.

Most groups showed preference for the $8 \mathrm{mg} / \mathrm{kg}$ dose of cocaine, a dose in which preference is expected (Campbell et al., 2000); however, animals sleep deprived before saline conditioning trials (noSD Coc, SD Sal, study 1) did not reach statistical significance for preference despite the majority of animals showing an increase in time spent on the cocaine-paired side from the pre to postconditioning tests $(8 / 12)$. This lack of preference is likely attributable to high variability in preference scores relative to the group average $(126.4 \pm 83.6)$ and is driven by a single animal as can be seen in Figure $1 B$, although this animal does not qualify as an outlier. As can be seen from the raw data plots with the $8 \mathrm{mg} / \mathrm{kg}$ dose across 
studies, most animals show an increase in relative time in the cocaine-paired side from pre to postconditioning, although not all animals do so. We cannot explain the source of the individual differences, but these are consistent with individual differences seen with locomotor sensitization to cocaine (Hooks et al., 1991; Allen et al., 2007) and cocaine self-administration (Glick et al., 1994; Griffin et al., 2007).

The ability of OX1R antagonism to reduce SD-induced enhancement of cocaine CPP is consistent with the wellknown role of orexin in motivated behavior (James et al., 2017) and maintenance of arousal (Sakurai et al., 2010). Orexin neuronal activity increases during SD (Estabrooke et al., 2001) as does orexin release (Yoshida et al., 2001). Furthermore, orexin agonists promote cocaine self-administration (España et al., 2011), while antagonism of orexin activity can reduce reward behavior (Sartor and Aston-Jones, 2012; Rao et al., 2013; Shaw et al., 2017).

The SD-induced enhancement of cocaine CPP is consistent with previous studies in which SD increases preference of methylphenidate in humans (Roehrs et al., 1999) and induces preference to a low dose of amphetamine in rodents (Berro et al., 2018). However, there are several additional studies that would be of interest in further delineating the ability of sleep loss to influence reward behavior. First, thus far, all studies have used stimulants so the generalizability of the SD-induced enhancement of preference across drug class is unknown. Additionally, the time course of this enhancement preference is unclear. A long-term enhancement of preference would likely be more relevant to the development of addiction than if the SD-induced enhancement is quickly lost. Finally, it is unknown whether SD-induced enhancement of stimulant reward is sustained in drug experienced animals since existing studies have included drug naive rodents or non-dependent humans.

These studies had several limitations. First, study 4 lacked a vehicle control group; a control group of noSD SB was used for the experimental group SD SB in which the ability of OX1R-antagonism to counter SD-induced enhancement of cocaine CPP to an $8 \mathrm{mg} / \mathrm{kg}$ dose of cocaine (from study 2) was tested. DMSO was diluted to reduce the concentration below that which behavioral effects are observed (Cavas et al., 2005). However, the effect of vehicle alone on CPP expression was not determined so the possibility that SD-induced enhancement of cocaine CPP was reduced by the vehicle cannot be excluded. Another limitation relates to the lack of direct statistical comparisons across related studies (studies 1 and 3 , studies 2 and 4) because of the manner of data collection. Within each study, control and experimental animals were littermates, and data were collected concurrently across groups with multiple sets of control and experimental animals collected for each study; however, there was a considerable time lag between data collection of related studies. A superior design would have included concurrent data collection for related studies so that these could be directly compared. Additionally, since activity measures are not available for conditionings performed with all of the CPP boxes, we cannot exclude a possibility that enhanced preference is associated with an increase in locomotor activity; however, we have previously shown that acute SD does not influence the magnitude of locomotor sensitization to cocaine (Bjorness and Greene, $2018 b)$ so an SD-dependent increase in locomotor activity is not expected. Finally, the current experiments did not include female subjects so it is unknown whether gender influences SD enhancement of cocaine CPP.

In conclusion, acute SD increases the rewarding properties of cocaine in a cocaine dose-dependent manner as measured by the CPP task which suggests that sleep loss may facilitate the transition toward addiction. OX1R antagonism reduces this effect, suggesting a potential therapeutic avenue for careful consideration as an aid in abstinence maintenance. Recently, Suchting and colleagues provided preliminary proof-of-concept for use of orexin receptor antagonism in individuals with cocaine use disorder (Suchting et al., 2020). Although the study design precluded an assessment of the efficacy of a OX1R/OX2R antagonist, there is evidence for its having improved objective sleep (actigraphy) and self-reported craving measures (Cocaine Craving Questionnaire), suggesting the clinical relevance for our findings.

\section{References}

Allen RM, Everett CV, Nelson AM, Gulley JM, Zahniser NR (2007) Low and high locomotor responsiveness to cocaine predicts intravenous cocaine conditioned place preference in male SpragueDawley rats. Pharmacol Biochem Behav 86:37-44.

Angarita GA, Canavan SV, Forselius E, Bessette A, Morgan PT (2014) Correlates of polysomnographic sleep changes in cocaine dependence: self-administration and clinical outcomes. Drug Alcohol Depend 143:173-180.

Bardo MT, Bevins RA (2000) Conditioned place preference: what does it add to our preclinical understanding of drug reward? Psychopharmacology (Berl) 153:31-43.

Berro LF, Tufik SB, Frussa-Filho R, Andersen ML, Tufik S (2018) Sleep deprivation precipitates the development of amphetamineinduced conditioned place preference in rats. Neurosci Lett 671:29-32.

Bjorness TE, Greene RW (2018a) Dose response of acute cocaine on sleep/waking behavior in mice. Neurobiol Sleep Circadian Rhythms 5:84-93.

Bjorness TE, Greene RW (2018b) Sleep deprivation alters the time course but not magnitude of locomotor sensitization to cocaine. Sci Rep 8:17672.

Bjorness TE, Kelly CL, Gao T, Poffenberger V, Greene RW (2009) Control and function of the homeostatic sleep response by adenosine A1 receptors. J Neurosci 29:1267-1276.

Bjorness TE, Kulkarni A, Rybalchenko V, Suzuki S, Bridges C, Harrington AJ, Cowan CW, Takahashi JS, Konopka G, Greene RW (2020) An essential role for MEF2C in the cortical response to loss of sleep. Elife 9:e58331.

Bozarth MA, Wise RA (1985) Toxicity associated with long-term intravenous heroin and cocaine self-administration in the rat. JAMA 254:81-83.

Brower KJ, Aldrich MS, Robinson EA, Zucker RA, Greden JF (2001) Insomnia, self-medication, and relapse to alcoholism. Am J Psychiatry 158:399-404.

Campbell JO, Wood RD, Spear LP (2000) Cocaine and morphine-induced place conditioning in adolescent and adult rats. Physiol Behav 68:487-493.

Cavas M, Beltrán D, Navarro JF (2005) Behavioural effects of dimethyl sulfoxide (DMSO): changes in sleep architecture in rats. Toxicol Lett 157:221-232. 
Chen B, Wang Y, Liu X, Liu Z, Dong Y, Huang YH (2015) Sleep regulates incubation of cocaine craving. J Neurosci 35:13300-13310.

Dolsen MR, Harvey AG (2017) Life-time history of insomnia and hypersomnia symptoms as correlates of alcohol, cocaine and heroin use and relapse among adults seeking substance use treatment in the United States from 1991 to 1994. Addiction 112:1104-1111.

Dugovic C, Meert TF, Ashton D, Clincke GH (1992) Effects of ritanserin and chlordiazepoxide on sleep-wakefulness alterations in rats following chronic cocaine treatment. Psychopharmacology (Berl) 108:263-270.

España RA, Melchior JR, Roberts DC, Jones SR (2011) Hypocretin 1/ orexin $A$ in the ventral tegmental area enhances dopamine responses to cocaine and promotes cocaine self-administration. Psychopharmacology (Berl) 214:415-426.

Estabrooke IV, McCarthy MT, Ko E, Chou TC, Chemelli RM, Yanagisawa M, Saper CB, Scammell TE (2001) Fos expression in orexin neurons varies with behavioral state. J Neurosci 21:16561662.

Gentile TA, Simmons SJ, Barker DJ, Shaw JK, España RA, Muschamp JW (2018) Suvorexant, an orexin/hypocretin receptor antagonist, attenuates motivational and hedonic properties of cocaine. Addict Biol 23:247-255.

Glick SD, Raucci J, Wang S, Keller RW Jr, Carlson JN (1994) Neurochemical predisposition to self-administer cocaine in rats: individual differences in dopamine and its metabolites. Brain Res 653:148-154.

Graham DL, Krishnan V, Larson EB, Graham A, Edwards S, Bachtell RK, Simmons D, Gent LM, Berton O, Bolanos CA, DiLeone RJ, Parada LF, Nestler EJ, Self DW (2009) Tropomyosin-related kinase $B$ in the mesolimbic dopamine system: region-specific effects on cocaine reward. Biol Psychiatry 65:696-701.

Griffin WC, 3rd, Randall PK, Middaugh LD (2007) Intravenous cocaine self-administration: individual differences in male and female C57BL/6J mice. Pharmacol Biochem Behav 87:267-279.

Hollander JA, Pham D, Fowler CD, Kenny PJ (2012) Hypocretin-1 receptors regulate the reinforcing and reward-enhancing effects of cocaine: pharmacological and behavioral genetics evidence. Front Behav Neurosci 6:47.

Hooks MS, Jones GH, Smith AD, Neill DB, Justice JB Jr (1991) Individual differences in locomotor activity and sensitization. Pharmacol Biochem Behav 38:467-470.

James MH, Mahler SV, Moorman DE, Aston-Jones G (2017) A decade of orexin/hypocretin and addiction: where are we now? Curr Top Behav Neurosci 33:247-281.

James MH, Stopper CM, Zimmer BA, Koll NE, Bowrey HE, AstonJones G (2019) Increased number and activity of a lateral subpopulation of hypothalamic orexin/hypocretin neurons underlies the expression of an addicted state in rats. Biol Psychiatry 85:925935.

Johanson CE, Balster RL, Bonese K (1976) Self-administration of psychomotor stimulant drugs: the effects of unlimited access. Pharmacol Biochem Behav 4:45-51.

Knapp CM, Datta S, Ciraulo DA, Kornetsky C (2007) Effects of low dose cocaine on REM sleep in the freely moving rat. Sleep Biol Rhythms 5:55-62.

McClung CA, Sidiropoulou K, Vitaterna M, Takahashi JS, White FJ, Cooper DC, Nestler EJ (2005) Regulation of dopaminergic transmission and cocaine reward by the Clock gene. Proc Natl Acad Sci USA 102:9377-9381.
Mucha RF, van der Kooy D, O'Shaughnessy M, Bucenieks P (1982) Drug reinforcement studied by the use of place conditioning in rat. Brain Res 243:91-105.

Nomikos GG, Spyraki C (1988) Cocaine-induced place conditioning: importance of route of administration and other procedural variables. Psychopharmacology (Berl) 94:119-125.

Puhl MD, Boisvert M, Guan Z, Fang J, Grigson PS (2013) A novel model of chronic sleep restriction reveals an increase in the perceived incentive reward value of cocaine in high drug-taking rats. Pharmacol Biochem Behav 109:8-15.

Rao Y, Mineur YS, Gan G, Wang AH, Liu ZW, Wu X, Suyama S, de Lecea L, Horvath TL, Picciotto MR, Gao XB (2013) Repeated in vivo exposure of cocaine induces long-lasting synaptic plasticity in hypocretin/orexin-producing neurons in the lateral hypothalamus in mice. J Physiol 591:1951-1966.

Roehrs T, Papineau K, Rosenthal L, Roth T (1999) Sleepiness and the reinforcing and subjective effects of methylphenidate. Exp Clin Psychopharmacol 7:145-150.

Ritz MC, Lamb RJ, Goldberg SR, Kuhar MJ (1987) Cocaine receptors on dopamine transporters are related to self-administration of cocaine. Science 237:1219-1223.

Sakurai T, Mieda M, Tsujino N (2010) The orexin system: roles in sleep/wake regulation. Ann NY Acad Sci 1200:149-161.

Sartor GC, Aston-Jones GS (2012) A septal-hypothalamic pathway drives orexin neurons, which is necessary for conditioned cocaine preference. J Neurosci 32:4623-4631.

Sharf R, Guarnieri DJ, Taylor JR, DiLeone RJ (2010) Orexin mediates morphine place preference, but not morphine-induced hyperactivity or sensitization. Brain Res 1317:24-32.

Shaw JK, Ferris MJ, Locke JL, Brodnik ZD, Jones SR, España RA (2017) Hypocretin/orexin knock-out mice display disrupted behavioral and dopamine responses to cocaine. Addict Biol 22:16951705.

Spyraki C, Fibiger HC, Phillips AG (1982) Cocaine-induced place preference conditioning: lack of effects of neuroleptics and 6-hydroxydopamine lesions. Brain Res 253:195-203.

Suchting R, Yoon JH, Miguel GGS, Green CE, Weaver MF, Vincent JN, Fries GR, Schmitz JM, Lane SD (2020) Preliminary examination of the orexin system on relapse-related factors in cocaine use disorder. Brain Res 1731:146359.

Thannickal TC, John J, Shan L, Swaab DF, Wu MF, Ramanathan L, McGregor R, Chew KT, Cornford M, Yamanaka A, Inutsuka A, Fronczek R, Lammers GJ, Worley PF, Siegel JM (2018) Opiates increase the number of hypocretin-producing cells in human and mouse brain and reverse cataplexy in a mouse model of narcolepsy. Sci Transl Med 10:eaao4953.

Tyree SM, Borniger JC, de Lecea L (2018) Hypocretin as a hub for arousal and motivation. Front Neurol 9:413.

Um HS, Kang EB, Koo JH, Kim HT, Jin L, Kim EJ, Yang CH, An GY, Cho IH, Cho JY (2011) Treadmill exercise represses neuronal cell death in an aged transgenic mouse model of Alzheimer's disease. Neurosci Res 69:161-173.

Yoshida Y, Fujiki N, Nakajima T, Ripley B, Matsumura H, Yoneda H, Mignot E, Nishino S (2001) Fluctuation of extracellular hypocretin1 (orexin A) levels in the rat in relation to the light-dark cycle and sleep-wake activities. Eur J Neurosci 14:1075-1081.

Zachariou V, Caldarone BJ, Weathers-Lowin A, George TP, Elsworth JD, Roth RH, Changeux JP, Picciotto MR (2001) Nicotine receptor inactivation decreases sensitivity to cocaine. Neuropsychopharmacology 24:576-589. 